\title{
Neoliberal control devices and social discrimination: The case of Paris Saint-Germain football club fans
}

\author{
Charles H. Cho ${ }^{\mathrm{a}, 1}$, Floriane Janin ${ }^{\mathrm{b}}$, Christine Cooper ${ }^{\mathrm{c}}$ and \\ Michael Rogerson $^{\mathrm{d}}$ \\ ${ }^{a}$ Schulich School of Business, York University, Canada \\ ${ }^{\mathrm{b}}$ HEC Paris, France \\ ${ }^{c}$ University of Edinburgh, $U K$ \\ ${ }^{d}$ University of Bath, UK
}

\begin{abstract}
Research Question: How is neoliberal control exercised over football fans? What is the effect of neoliberal control devices on football fans?

Motivation: We draw upon Foucault's work to explore the various disciplining control devices targeting Paris Saint-Germain Football Club (PSG) fans. At a time of increasing social strife in France, Yann Lorence was killed in a factional dispute between two PSG "ultra" fans groups in 2010. Following this, drastic measures were taken to tighten control over various PSG fan groups. After the acquisition of PSG by Qatar Sports Investments (QSI) in 2011, these control measures were reinforced to the point where they came under the scrutiny of the French commission protecting individual liberties (CNIL) - as one of them resulted in the exclusion of some fans directly from or around the stadium on reportedly "arbitrary" - but actually social - grounds.

Idea: We explore the extent to which going one degree further into the market society and implementing a neoliberal rationality can impact social life. More specifically, we examine how social discrimination can be created and encouraged through neoliberal control devices.

Data: We use both "netnographic" data and interviews with key actors and stakeholders in the football field.

Tools: We examine and analyze the neoliberal control devices implemented by PSG management, in collaboration of the French government, in order to change the sociodemographics of its fan base and ultimately change its image and identity, to consider the operation of control systems from a Foucauldian perspective.
\end{abstract}

${ }^{1}$ Corresponding author: Charles H. Cho, Schulich School of Business, York University, Canada, email address: ccho@schulich.yorku.ca 
Findings: The various methods of control exercised by and around the club significantly blurred the distinction between PSG as a private enterprise and the French state as a legislative/judicial entity. This resulted in fan self-exclusion and self-policing ("control of the self"), and also the enforced removal of a largely working-class portion of the club's fans.

Contribution: We contribute to the study of the articulation of "discipline" and "government" (the two major power techniques in Foucault's work) and to the management control literature by showing how neoliberal control devices can discriminate against people on sociological grounds, thereby impeding the development of an equal and harmonious social life.

Keywords: Foucault; control; neoliberal; discrimination; football; football fans; Paris Saint-Germain

\section{JEL codes: $M 41$}

"In 2016 PSG upgraded the stadium, more than doubling the number of VIP seats to about 4,500. Tom Sheehan, the project's architect said: 'What PSG wanted us to do was look at how we could breathe the identity of Paris into the Parc itself. Paris is a very luxurious destination. We've tried to make the Parc a chic destination.' He likened the stadium's renovated VIP entrance to the entrance hall of Paris's Opéra Garnier, 'where people come early, to see and be seen'. Young banlieusards drinking beer and smoking pot on the surrounding pavements didn't fit PSG's plan." (Kuper, 2020: 8)

\section{Introduction}

The French state's inability to unify and unite its citizens has led to outbreaks of highly violent acts. For example, in recent times, significant social unrest has been created by young people in French "banlieues" (slums) in 2005; opponents to gay marriage from 2012 to 2014; opponents of a new airport at Nantes from 2012 to 2018; and in Brittany against the creation of a green tax on road freight transport in 2013. Police responses to these (turning violent) protests could be, at best, described as "heavy-handed". In August 2019, the French press reported that President Emmanuel Macron angered police unions when he announced that there were "unacceptable injuries" suffered by both police and protesters during the months of "gilets jaunes" ("yellow vests") protests. ${ }^{2}$ Various French intellectuals, journalists, politicians and commentators have tried to find explanations for these circumstances. The market society is often blamed as unable to create, organize and keep alive social links between people (see, for example, Detchessahar, 2015).

2 See https://www.francetvinfo.fr/economie/transports/gilets-jaunes/demagogique-vexanttardif-reactions-mitigees-a-la-volonte-affichee-par-emmanuel-macron-de-repenser-lesmethodes-d-intervention-des-forces-de-1-ordre_3586651.html [Accessed 6 September 2020] 
Traditionally, the form of the French economic system was "social capitalist", but tends now towards more neoliberal ways of governing.

Using the case of the Paris Saint-Germain Football Club (PSG), this paper explores the extent to which going one degree further into the market society and implementing a neoliberal rationality can impact social life. The violence perpetrated by the state as an increasingly neoliberal actor has also been reflected in the sphere of football, especially regarding PSG (Kuper, 2020; Tsoukala, 2013). In recent years, PSG, after the death of a fan in a factional dispute between two "ultra" groups, made drastic changes to the way in which the club is managed (from the Leproux plan to the Qatari ownership), leading to a neoliberal style of governance. We thus examine (i) the control devices serving this neoliberal rationality, and (ii) the evolution of the social well-being of fans, which has been taken so far beyond what was required for the physical safety of spectators, that we argue it exposes a machinery of control using fan safety concerns as a mere excuse. We show that if the situation appears to have improved (as there is no more violence within the stadium), it is in fact not much better (violent fans are free in the "real life", and usual social communities of fans have disappeared). We contribute to the literature by showing how neoliberal control devices choose a social demographic to discriminate against, thereby impeding the development of a harmonious social life.

The remainder of the paper is structured as follows. The next section provides a literature review on the interrelations between control devices and social issues. Section 3 presents the Foucauldian framework within which the paper is developed. Section 4 presents the background and context of our case football club-the Paris Saint-Germain Football Club. Section 5 addresses our research methods. This is followed in section 6 by the analysis of the case, specifically illustrating how neoliberal control devices impact the social well-being of football fans. The paper ends with a discussion and conclusion.

\section{Literature review - Control devices and social issues}

\subsection{Control both enables and constrains}

A well-known debate in the management control literature deals with the enabling or constraining capabilities of control. Previous research tends to highlight one aspect of these capabilities (enabling or constraining) in particular, while often recognizing the possibility of the other. Indeed, the duality of the structure, as defined by Giddens (1979), is often acknowledged.

If the constraining power of control is more obvious, many studies also investigate its enabling aspects. For instance, the role played by management control systems 
in the process of strategy formulation has been emphasized. Simons (1990: 128) highlights the usefulness of management control systems "in empowering organizational learning and interactively influencing strategy". The literature also emphasizes the enabling capabilities of management control systems. Ahrens and Chapman (2007: 24) state that, "As such the key question for management control theory is not how to constrain individuals and overcome resistance. Rather, it needs to bring into focus the possibilities of management control systems as a resource for action". As a result, there is a focus on management control practices and their enabling role in action: "Management control functioned as structures of intentionality, not coercively, but by enabling [...] managers [...] to think through the strategic potential of past and potential actions" (Ahrens and Chapman, 2007: 15). A commonality within this literature is a lack of critique on the legitimacy of these control systems, which we demonstrate as weak; as extensions of state, as well as a private entity's, violence.

\subsection{Control can create social issues}

Some research has shown how control technologies can be built to serve dominant interests (Uddin, 2009; Farjaudon \& Morales, 2013). Farjaudon and Morales (2013: 155) argue that this use of control technologies can be found in different sectors:

"Studies examining the introduction of budgets in hospitals (Preston et al., 1992), business planning in museums (Oakes et al., 1998), new funding mechanisms in education (Neu, 2006) and comprehensive auditing in national parks (Everett, 2003) all highlight accounting and control technologies as elements of ideological projects that favor the interests of some at the expense of others."

Thus, control technologies are not exempt from power, domination and ideological characteristics, and can potentially entail social issues. "Device" is a Foucauldian term, defined as,

"a resolutely heterogeneous set of discourses, institutions, architectural plans, regulating decisions, laws, administrative measures, scientific terms, and philanthropic, moral and philosophical propositions; in a word: said and non-said, here are the elements of the device. The device itself is the network that one can establish between these elements." ${ }^{3}$ (Foucault, 1994: 299)

\footnotetext{
${ }^{3}$ Our translation of the original version: « un ensemble résolument hétérogène, comportant des discours, des institutions, des aménagements architecturaux, des décisions réglementaires, des lois, des mesures administratives, des énoncés scientifiques, des propositions philosophiques, morales, philanthropiques, bref : du dit, aussi bien que du
} 
Foucault discusses power devices, or control devices, to analyze the overall mechanisms surrounding the diffusion of power. The term comprises technical, political, moral and social aspects. Foucault's work has been used in the accounting literature to show disciplining and self-subjecting aspects of accounting and management control devices at work within organizations (Knights \& Collinson, 1987; Covaleski et al., 1998).

\section{A Foucauldian framework}

To set up the characteristics of the field of football, we begin by reflecting upon Bill Clinton's reaction to Qatar being awarded the hosting of the 2022 World Cup, the sport's most prestigious competition:

"Bill Clinton looked anything but happy as he strode into the Savoy Baur en Ville hotel in Zurich in December 2010. The receptionists could tell he was irritated but had no idea just how angry he was.

After closing the door to his suite, he reached for an ornament on a table and threw it at a wall mirror in a fit of rage, shattering the glass.

The former US president, who had spent two years travelling the world glad-handing members of football's governing body, FIFA, could not believe America's bid to host the 2022 World Cup had been beaten by, of all places, Qatar.

Mr Clinton, the honorary chairman of the US bid, had wheeled out such big hitters as Brad Pitt, Arnold Schwarzenegger, Morgan Freeman and Spike Lee to add lustre to the US Soccer Federation bid. Australia and Japan's bids had seemed the biggest threat, but few had seriously entertained the idea that Qatar, a footballing desert, could win.

'Clinton was fuming,' said one well-placed source. 'He felt humiliated and felt the decision did not make sense'." (Watt et al., 2014)

To an outsider, the award of the right to host the World Cup to Qatar raises very important and interesting questions about the state of geopolitics in 2010. Surely such a powerful world leader as Bill Clinton with the backing of one of the most powerful countries in the world would be able to win a bid (against the historically "non-footballing" nations of Australia, Japan and Qatar) to host a tournament in a sport emerging in popularity in the United States? How could FIFA, a private, unelected organization have the power to humiliate the US? In order to answer these questions, and to set the context for the analysis of this paper, we draw on the work of Michel Foucault.

non-dit, voilà les éléments du dispositif. Le dispositif lui-même, c'est le réseau qu'on peut établir entre ces éléments » (Foucault, 1994: 299). 
In a series of 1977-78 lectures on "security, territory, and population" (2004a), and then in the "birth of biopolitics" (2004b), Foucault introduced a new problematic of biopolitics ${ }^{4}$ and governmentality. To Foucault, governmentality is more diffuse than residing simply in the state. It can be found at the intersection of massive global corporations, supra-state governance bodies and nation states.

In the case of football, the supra-state governance bodies include FIFA (world football's governing body, Fédération Internationale de Football Association), UEFA (European football's governing body, the Union of European Football Associations) and the national football regulatory bodies. The massive global corporations include SKY, beIN SPORTS, and other satellite TV and internet providers as well as the large corporations which own football clubs. These telecommunications corporations are prepared to pay national and transnational football bodies huge amounts of money to be able to exclusively show the matches of their various competitions. The viewing rights to these matches are then sold to subscribers, many of whom might not subscribe for the Internet, TV and phone services provided by the global corporations without them.

Nation states are tasked with providing the same infrastructure and regulatory functions as they would to any other global corporations. However, (partially) at the clubs' expense, the state also provides police (and where necessary the army) to ensure crowd discipline at football matches. For the purposes of the argumentation in this paper, each of the sport's powerful (largely unelected and unaccountable) governing bodies has the power to create and enforce their own rules, frequently at the expense of the rights of the people. Indeed, FIFA and UEFA will expel clubs who seek redress in courts outside of the domain of football. ${ }^{5}$

The award of the hosting of the World Cup to Qatar is indicative of the power dynamics among groups that are able to join and leave depending on their own interests. If the bid from the US had been the winner, there is little doubt that the US would have done much to contribute to the success of the 2022 World Cup in a manner that, though based on neoliberal principles, would not have seen the human

${ }^{4}$ Biopolitics is a form of "political rationality". It is concerned with the administration of citizens. In the development of capitalism, the bourgeoisie ensured that this rationality created the disciplined bodies required for the emerging market economy (Foucault, 2003).

${ }^{5}$ See https://www.bbc.com/sport/football/15793733

The BBC reports that UEFA has insisted that the Court of Arbitration for Sport (CAS) is the only valid authority with jurisdiction over football matters. This came to a head when Sion FC claimed that the UEFA had "breached its players' working rights under the European Union-Swiss treaty" (BBC, 18 November 2011). By its insistence on using CAS, Sion FC claimed that UEFA had "denied the club access to an independent and impartial judge"” (BBC, 18 November 2011). Perhaps more importantly, UEFA rules trumped Swiss and European law. 
rights and "sport-washing" in evidence in Qatar (Næss, forthcoming). ${ }^{6}$ However, we will demonstrate in this paper that in the midst of the machinations of the most powerful forces in football, the hopes, dreams and pleasures of football fans are being crushed while at the same time, they are being denied some of their rights. To many, the "abuses of the rights" of football fans may seem trivial or less important than many of the abuses of human rights which are perpetuated on a daily basis, and we agree with the later sentiment. However, we argue that football is an important international cultural form and, perhaps more importantly, it provides an interesting terrain on which to consider social discrimination during the current period of neo-liberal governmentality. One of the game's most decorated coaches, Arrigo Sacchi, is said to have described this dichotomy thus: "Football is the most important of the least important things in life" (Horncastle, 2018).

According to Lemke (2001), Foucault's concept of governmentality conceptualizes the reciprocal constitution of "power techniques" and "forms of knowledge". As he sets out, "the semantic linking of governing ('gouverner') and modes of thought ('mentalité') indicates that it is not possible to study the technologies of power without an analysis of the political rationality underpinning them", and as he concludes, "in other words, there are two sides to governmentality" (Lemke, 2001: 191). Governmentality is a technology of power that takes charge of the lives of subjects. Foucault's theories can be used to address the interweaving of Marx's infrastructure and superstructure, and to establish a historical sequence of increased sophistication in the technologies of domination employed by modern capitalism: first "sovereignty," then "disciplines," and, finally, biopolitics (Reyes-Zaga, 2014). What is new in $21^{\text {st }}$ century control devices is the transit from the governmentality ${ }^{7}$ of classical liberalism to that of current neoliberalism, which, as alluded to above, goes beyond the legal order of the nation state and thus has profound implications for human rights. Reyes-Zaga (2014) points out that for Hardt and Negri (2000), "the state is no longer the single imperial political machine capable of reducing the human being to a mere disposable body or administering it as such; the global advent of neoliberalism has led to the emergence of legal or illegal economic elites so powerful that, like the state, they can transform the capital body into a superfluous body in an instant." Human bodies are now exposed to violence from both the state and the economic power. Indeed, they argue that capitalist accumulation and expansion has followed a path of increasing economic, political, and cultural domination - to the point that, today, it controls the most intimate strands of every living body in all corners of the world. In the next section, we turn to our case of PSG.

${ }^{6}$ In the 2014 World Cup, Brazil overturned its ban on alcohol in stadiums at the behest of FIFA.

7 "Governmentality," which Foucault also calls the "art of government" and "governmental rationality," is nothing more than a system of thought regarding the nature and practice of government and the behaviours they drive (who governs, how, who is governed) within precise historical coordinates.

Vol. 19, No. 3 


\section{The case of Paris Saint-Germain Football Club}

In football terms, Paris Saint-Germain Football Club (PSG) is a relatively young club, having been formed in 1970. From 2006 to 2011, PSG was primarily owned by Colony Capital. ${ }^{8}$ For PSG, this was a period of mediocre football performance. ${ }^{9}$ Aside from underperforming on the pitch, PSG became renowned for having fans who literally fought with each other. The history and evolution of the PSG fan base is quite complex. By the late 2000s, the behavior of those fans over the course of a dozen years had severely damaged the club's reputation both nationally and internationally (Doyle, 2006). These issues came to a head during the 2009-2010 season (Tsoukala, 2013). At this time racist and territorial issues between two dominant fan groups from the oppositely located Boulogne and Auteuil seating areas of the stadium ("virages" in French, which are the cheaper and popular stands) came to a head. These fans were from very different socio-political backgrounds and demographics: those embracing neo-Nazi ideologies vs. relatively younger ones from the "banlieues", with diverse origins. The rivalry intensified and was punctuated by violent fights (Mouillard, 2010). Because of the violence and hooliganism, children and women became more or less absent from the stadium. On February 28, 2010 before the match against Marseille (PSG's most important rival), the existing tension between the Auteuil and Boulogne stand fans led to violent fights and eventually resulted in the death of one fan from the Boulogne stand (de Sa Pereira, 2012).

The club's president at that time, Robin Leproux, took drastic measures after this tragic incident. As a "clean-all" strategy, he banned and dissolved all official PSG fan groups without making any distinctions between them. This first step has been referred to as the "Leproux plan" (Tsoukala, 2013). This new plan stipulated that anyone purchasing a ticket would be given a randomly assigned seat. Moreover, it was only possible to buy seats for one or two other people at the most. This policy was designed to avoid the gathering of fans in the stadium and to prevent the formation of any potential informal (or formal) fan group (Kuper, 2020). In addition, season tickets were no longer available for sale in the Boulogne and Auteuil stands. As a result of this radical change in stadium management, there was a significant reduction in levels of violence, since it was made virtually impossible for fans to get together. However, given that it was the fans who used to make PSG's legendary stadium the Parc des Princes' atmosphere very lively - it became known as "la caisse de résonance" ("the sound box"), an effect created by

8 This is a U.S-incorporated, privately held, digital infrastructure, real estate, and investment management firm.

9 The club, which had been champions twice before, was barely saved from relegation. In the seven seasons prior to 2011 , PSG had finished $4^{\text {th }}, 13^{\text {th }}, 6^{\text {th }}, 16^{\text {th }}, 15^{\text {th }}, 9^{\text {th }}$ and $9^{\text {th }}$. 
coordinating "tifos"10 and organizing fans' singing (Navarro, 2015) - the stadium did not look nor sound the same at all. The atmosphere and the fan demographics began to slowly but drastically change. In terms of individual fans, Leproux's measures initially targeted only the 1,200 "ultras" who had season tickets in the Boulogne and Auteuil stands (Shea, 2018). It seemed to be acknowledged that many fans who sat in these stands were not members of the ultra-groups; they chose to sit in these stands because ticket prices were more affordable, and they had a vibrant atmosphere.

In 2011, Qatar Sports Investments (QSI) took a 70\% stake in PSG (Reiche, 2015). Le Monde suggested that the new Qatari owners paid between $€ 30$ million and $€ 40$ million $^{11}$ for it. QSI belongs to Qatar Investment Authority (QIA), which is Qatar's sovereign investment fund. In 2012, QSI acquired the remaining 30\% stake to become PSG's sole shareholder. At that time, the club was valued at $€ 100 \mathrm{~m}^{12}$ In the same year, Jean-Claude Blanc (the PSG managing director at that time) said: "we have the right to welcome the people we want [in the stadium]". ${ }^{13}$ QSI banned 13,000 fans from the Boulogne and Auteuil stands (Shea, 2018). PSG also began to purchase "star" (very expensive, famous) football players during that period. This led to large increases in ticket prices (Shea, 2018, reports that prices in the Boulogne and Auteuil stands went up by $70 \%$ in the first year of QSI ownership). However, such an increase in ticket prices was more of a strategic manoeuvre by PSG management who were in fact following the English football strategy, which rationalized that expensive ticket prices would "keep out the riff-raff" (Malcolm et al., 2000). The stadium remained full of spectators, but the demographic of a stadium-goer had changed, excluding many traditional football fans. While this was also occurring elsewhere in Europe (e.g. England), in the case of PSG, some commentators, like Shea (2018), considered that the death of a fan "provided a convenient pretext through which PSG could achieve the gentrification of its support". Shea (2018) reports that Jérôme Latta (Le Monde) "accused QSI of socially engineering PSG's support base" and mentions Nicolas Hourcade, France's leading sports sociologist, describing PSG as wanting a "pliable fan base composed solely of consumers".

10 Tifo is the name for any choreography displayed by fans in the stands of an arena or stadium in connection with a sport event. In football, it mainly means a display of (for example) a whole stand (or even stadium) of fans holding up cards which produce a mosaic of a symbol or slogan.

11 See https://www.lemonde.fr/sport/article/2011/05/31/le-rachat-du-psg-s-inscrit-dans-lapolitique-nationale-du-qatar_1530110_3242.html

12 See https://www.lefigaro.fr/flash-eco/2012/03/06/97002-20120306FILWWW00534-psg30-des-restants-vendusaux-qatars.php

${ }^{13}$ See https://www.leparisien.fr/sports/football/psg/jean-claude-blanc-on-a-le-droit-daccueillir-le-public-qu-on-souhaite-27-09-2012-2183278.php 
The French state, rather than considering the human rights of its citizens, completely supported PSG in its treatment of its fans. It seemed that when PSG broke laws, the government would retroactively legalize PSG's activities (Shea, 2018). For example, and as mentioned by Shea (2018), the Conseil d'État prohibited PSG from blacklisting or collating dossiers on its fans, but a few days later, the French Minister of Interior passed a statutory instrument to legalize these acts; and in 2016, an Act allowed clubs to collect data on their fans. To be fair, PSG fans were not the sole football-fan targets of French state violence. Shea (2018) reports that the Hollande administration $(2012$ - 2017) allowed police to use flash-balls ${ }^{14}$ against fans in Montpellier, Strasbourg, Paris and Marseille in 2014. Furthermore, Shea (2018) argues that the degradation of football fans was part of the political discourse - the Interior Minister told the Senate that what the country needed now "was a football without football fans". In 2016, the state conflation of football fans with hooligans was codified in an Act, "Strengthening Dialogue with Fans and Fighting Hooliganism" (Loi $n^{\circ}$ 2016-564 du 10 mai 2016 renforçant le dialogue avec les supporters et la lutte contre le hooliganisme). The Act grants extraordinary powers over the rights of French citizens to freedom of movement. Shea (2018) emphasizes enlightening examples such as the prefect of the Paris region being able to ban any resident of the Nord-Pas-de-Calais from returning home for a 24-hour period; away fan travel possibly being prohibited or worse; or matches being played with no fans in attendance at all (so-called "behind closeddoor" games). These new powers were used on numerous occasions. The response of fans has been measured. The National Association of Fans (Association nationale des supporters), while fighting against travel bans, did not ask for impunity, but that individuals are only sanctioned, if necessary.

The local French football regulatory body, the Ligue de Football Professionnel (LFP) is in a difficult position. The state of Qatar owns beIN SPORTS (beIN Media Group), the television corporation which owns some of the rights to Ligue 1 football, and so is the main source of revenue for the LFP. This means that the owners of PSG (partially) fund LFP - threatening its "impartiality". The LFP itself is part of a network of international football regulatory bodies.

In this section, we have set out the domain in which PSG operates. It comprises the French state, football governing bodies and PSG owners - the state of Qatar, which owns a massive global TV corporation playing a key role in the French football field. Given the novelty of this context, we formulate the following research questions:

How is neoliberal control exercised over football fans? What is the effect of neoliberal control devices on football fans?

${ }^{14}$ Shea (2018) defines flash-balls as "handguns that fire rubber projectiles at the speed of regular ammunition". 


\section{Research methods}

In August 2014, we collected comments made by people at the end of online articles dealing with PSG's new policies towards fans. It appeared that most people writing comments at the end of these articles were PSG fans. We also collected comments made by US-expatriated PSG fans on the PSG Club New York Facebook Fan Page. We believe that collecting opinions from French-based and foreign-based PSG fans was interesting as we could gain insights into potentially different views. In all, this amounted to 30-word pages, which we coded in an inductive way. Sub-categories emerged. We grouped them into bigger categories. Categories were not forced but emerged spontaneously. In November 2015, we added another 13-word pages of comments (coming after three particular posts) collected on the PSG Club New York Facebook Fan Page.

Between October and December 2014, we conducted five semi-structured interviews (Table 1) with well-known football actors: two journalists, one former player, and two PSG fans having responsibility for fan groups.

Table 1. Interviews

\begin{tabular}{ccllc}
\hline No. & $\begin{array}{c}\text { Respondent } \\
\text { code }\end{array}$ & \multicolumn{1}{c}{ Role } & \multicolumn{1}{c}{ Date } & Duration \\
\hline 1 & A & $\begin{array}{l}\text { Former professional player } \\
\text { and sports consultant }\end{array}$ & October 8, 2014 & 29 minutes \\
2 & B & PSG fan group leader & October 20, 2014 & 26 minutes \\
3 & C & Former PSG fan group leader & November 27, 2014 & 39 minutes \\
4 & D & Sports journalist 1 & November 29, 2014 & 28 minutes \\
5 & E & Sports journalist 2 & December 5, 2014 & 32 minutes \\
\hline
\end{tabular}

Each interview lasted around 30 minutes on average, and was recorded and transcribed. We inductively coded the interviews and obtained 7-word pages, which gathered quotations of particular interest.

Given that our aim was to understand how new control devices implemented by PSG were perceived by its fans, the entire data analysis process was guided both by our research questions and the Foucauldian theoretical framework.

Collecting and analyzing "netnographic" data enabled us to understand how the experience of PSG fans had changed and gain access to relatively authentic opinions. Conducting interviews with key football actors was useful to ask some 
precise questions and collect views from people who actively contribute to the football field.

\section{Findings}

\subsection{Neoliberal control devices are based upon disciplinary power}

The accounting literature argues that accounting can serve as a crucial technology of neo-liberalism (see for example, Arnold, 2009; Arnold, 2012; Cooper, 2015; Covaleski et al., 2013; Jupe, 2012). It enables the rationalities of neoliberalism to pass through and thereby transform the organization and create new organizational practices.

\subsubsection{A panopticon within and without the stadium}

According to Foucault (1975), disciplinary power is implemented on bodies. As an extension of Foucault's discipline, we also understand that this implementation can lead to a form of disciplining of the self, a "denial of the self" depicted in Orwell (Tyner, 2004). In the case of PSG, the stadium functioned as an enclosure in which bodies must be watched and ruled. These bodies had rules to follow (no violence, no standing, no megaphones, no songs). The pictures (Images $1 \& 2$ ) taken in the Parc des Princes by one of the authors on April 5, 2014 provide evidence of this constant and intense monitoring of fans.

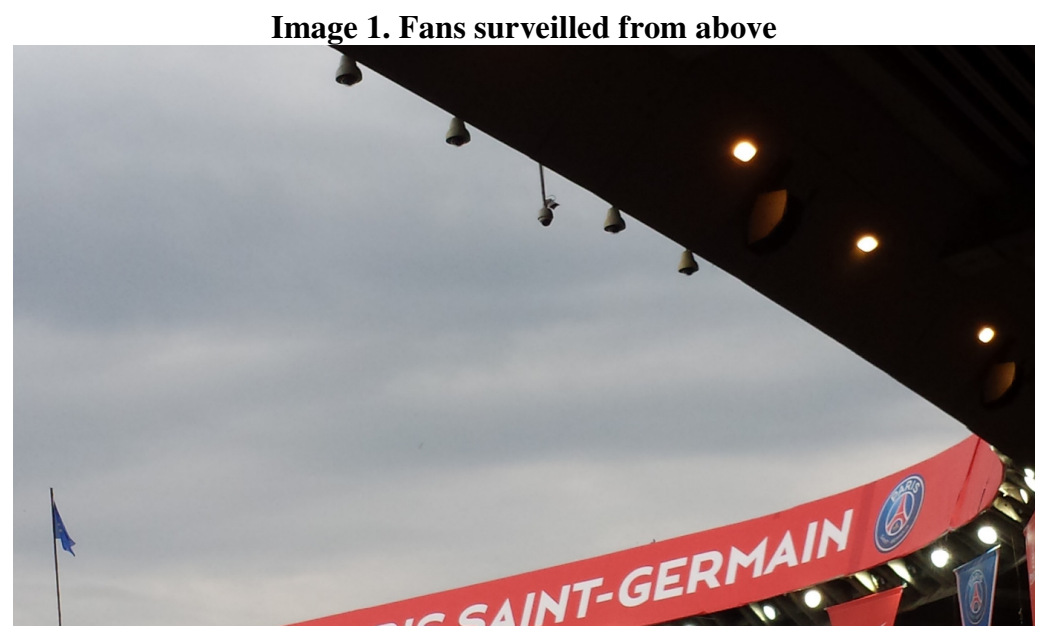




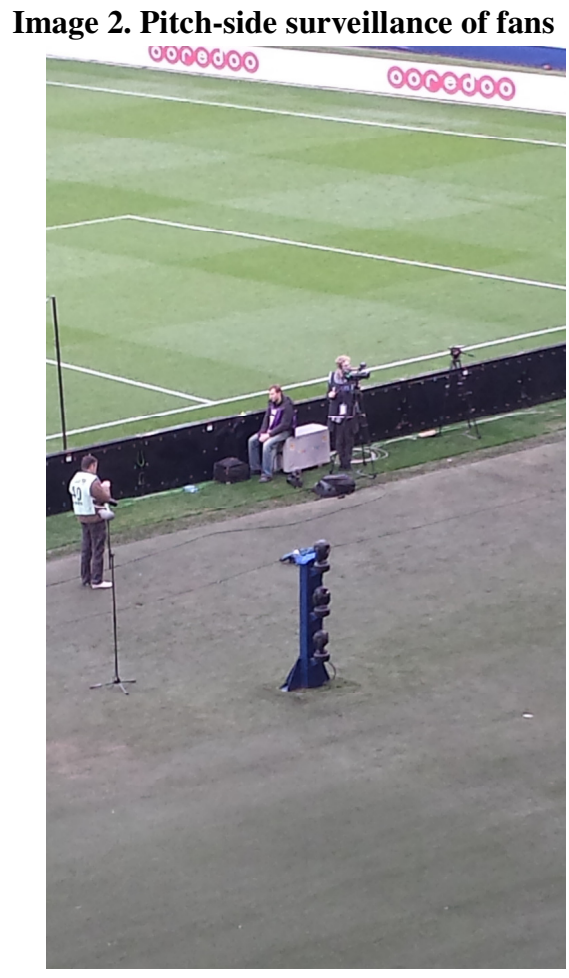

There was indeed a "panopticon"15 in the stadium through the different modes of surveillance-for example, closed circuit television (CCTV) cameras, stewards watching the audience while the audience watches the match; however, fans were not conscious of being observed at all times, and visibility/invisibility is a key dimension of the panopticon. Fans had no easy way of resisting this recording/surveillance. Moreover, PSG wanted to avoid any organization of fans into groups, and power is more efficient when directed towards individuals. According to Knights and Collinson (1987), managers had the power to individualize workers, which reinforced their vulnerability to a financial calculus. Foucault (1975) shows how the individualizing of population is important in designing technologies of power. PSG tried to control a "group" power of fansthose making noise and/or singing within the stadium. By becoming silent and alone, the fan was dominated. Behavior was strictly controlled within the stadium. Fans could not go alone to their seats. As one of them said: "When you arrive at the stadium, there are 7 women to show your way to your seat [...] even if you have

${ }^{15}$ Originally a conception (by the English philosopher and social theorist Jeremy Bentham) of a prison in which all prisoners could be watched by a single guard (Bentham, 1995) later espoused by Foucault (1975) as a metaphor for the modern disciplinary society. 
been coming to the stadium since you were born."16 Other stewards watched fans and took them to the police if they fail to obey rules (i.e., no smoking, no banners, no megaphones, etc.). This resulted in a sterile atmosphere at games, where the vibrant colors and passionate chanting and singing of PSG fans were replaced by a subdued environment (see Image 3, picture taken by one of the authors on April 5, 2014). Some fans received an exclusion letter from the stadium for breaking the rules. If a fan was seen wearing a scarf with the name of one of the old fan groups, she/he would be taken straight to the police during the match (and would be temporarily excluded from the stadium). There were disproportionate levels of security for those entering the stadium (fans had to pass through significant security blocks set up by the police and stadium stewards). The presence of both state and PSG security confronted fans as soon as they arrived in the vicinity of the Parc des Princes.

Image 3. A lack of banners and flags demonstrates the new sterility of the stadium experience

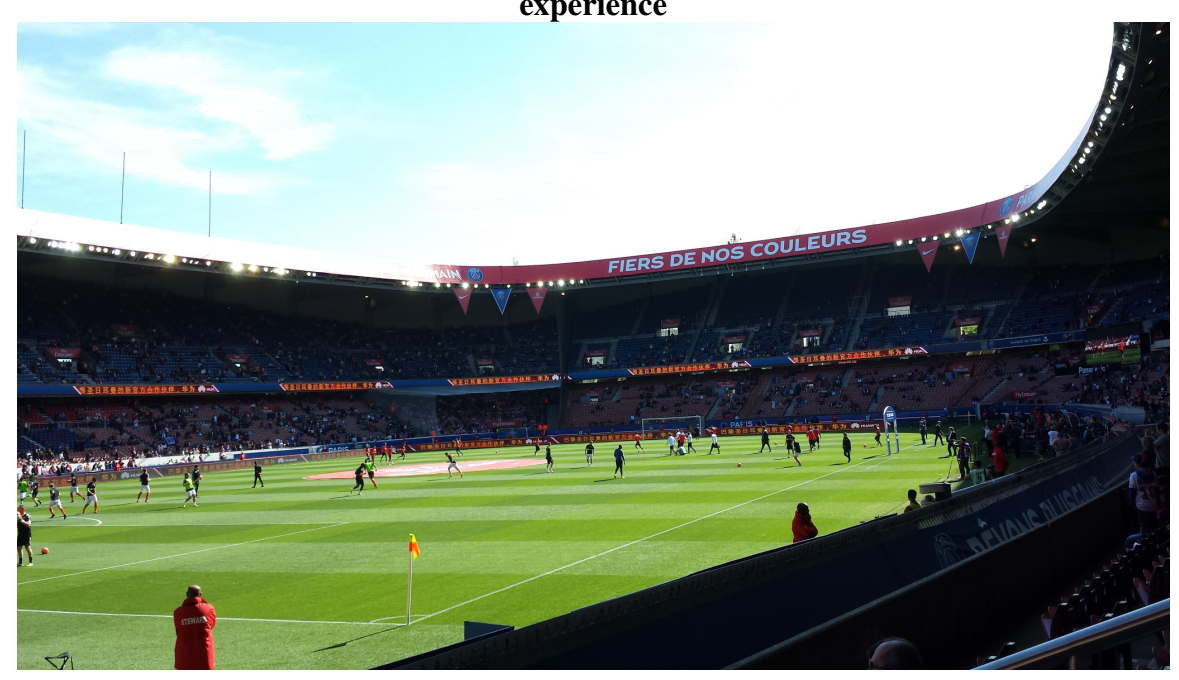

Beyond recording fan behavior (and indeed beyond the sole focus of PSG control), there was a bigger panopticon outside the stadium, where strict control of people authorized (or not) to buy tickets through a "blacklist" of fans existed. Those in that list were systematically denied entrance to the stadium. This regulation was approved by judges, which made this blacklist appear legitimate. There was also a second blacklist of "potential" problematic fans (about 2,000 of them at the time of our data collection) who regularly had their tickets cancelled by PSG one week before a given match or sometimes on match day. Moreover, PSG fans increasingly reported the feeling of being "spied on social media". ${ }^{17}$

${ }^{16}$ February 25, 2013 (PSG Club New York Facebook Fan Page).

${ }^{17}$ FB NY, Comments on the "It's official! If you are a PSG fan, you are a target!" post. 
According to Foucault, the disciplinary power of the panopticon acts through selfsubjection. ${ }^{18}$ Foucault (1975: 234) explains that the main objective of the panopticon is that "surveillance is permanent in its effects, even if it is discontinuous in its action". Thus, even if nobody stayed behind the cameras (and even if nothing was recorded), fans had the feeling of being watched; therefore, they complied with the different policies. The goal of our research is to consider this aspect of "self-surveillance" more closely. In other words, to consider the processes by, and the extent to which, control systems alter our subjectivities. Miller and O'Leary (1994) present a case study, which sets out the multinational corporation - Caterpillar's attempts to reconstruct the subjectivities of workers into "entrepreneurial units" (instead of workers) in its US Decatur plant. Miller and O'Leary (1994) describe how the physical reconfiguration of the Caterpillar plant into new manufacturing cells/modules were important for the "creation of entrepreneurs". The new cells/modules were to be understood as the "small businesses" of the newly subjectivized worker/entrepreneurs. The workforce was given the accounting numbers to show how uncompetitive Caterpillar was, and encouraged to see themselves, not as workers, but as entrepreneurs tasked with finding cost savings and efficiencies within their units. Miller and O'Leary (1994) add important contextual detail on how different forms of knowledge and practice make "the governable person" possible (Miller \& O'Leary, 1987). The case demonstrates the multiple agents involved in the neo-liberal project of entrepreneurializing workers. A slightly different perspective on the Caterpillar case was found by Arnold (1998). Arnold's interviews with Caterpillar staff suggest they were more animated by material threats of job losses than by abstract concepts of workplace autonomy and self-actualization promised by the spatial reorganization of the plant into modular cells. Indeed, Arnold's interviews suggest that the workers were completely aware of the management strategy to reconfigure the workforce and "governable entrepreneurs". As Cooper (2015) argues, the Caterpillar case poses a question regarding the extent to which technologies of control can impact upon the constitution of subjectivity. And perhaps, more importantly, do attempts to alter your subjectivity rely upon you not understanding what is happening to you? Nevertheless, both Miller and O'Leary (1994) and Arnold (1998) agree that the targets of discipline were the working class.

\subsubsection{A specific social class is targeted}

We too argue that panopticon-based control devices such as (self-)monitoring and restriction of access are used by PSG as a disciplinary technique targeting a

${ }^{18}$ In the PSG football fan case, by "self-subjection" we mean that - for example regarding the "no smoking" rule - people around fans watch them in the stadium, and fans are watched by cameras. Therefore, fans tend to subject themselves to that rule to avoid the stadium exclusion (which is the ultimate punishment for a fan) and do not smoke. Or and this would even be more powerful - in the case they absolutely need smoking, they no longer come to the stadium.

Vol. 19, No. 3 
specific social class. Knights and Collinson (1987) identified the class-specific power of accounting, by showing the disciplinary power of financial accounts over male manual workers in a shop floor. Threatened by a redundancy audit, these workers gave up and eventually accepted "the numbers" presented by management. According to Knights and Collinson (1987), financial numbers refer to an economic reality to which male manual workers are especially sensitive and vulnerable. Although workers resisted the psychological discipline from human resource managers because of their mistrust of management, they failed to resist the financial audit and lost their jobs. Workers self-subjected to the numbers, as they share materialist and unambiguous characteristics with them.

For Foucault, this shift towards the policing of the social body was related to the political economic consequences of the 18th century demographic transition, which created a need to integrate rapidly increasing numbers of people into the apparatus of production and to control them closely (Curtis, 2002). In the case of PSG, we identified control devices as targeting the working class, an assertion that fits with Foucault's later thought which sees class as an important, if not primary, factor (Ryder, 2013). Just as Knights and Collinson (1987: 457) consider accounting "not simply as a set of neutral techniques but as a political process, one effect of which is to lend support to management's control over labour", we argue that PSG's control devices were constructed to implement a class-specific disciplinary power, thereby discriminating against fans on sociological grounds. Indeed, some fans suspected that there was a connection between the ticket price increase and the club's desire to select fans based on their social backgrounds. Most of them clearly denounced the club's efforts to put barriers against working-class and poor people by increasing ticket prices:

I attended and watched Canadians' matches (ice hockey) more or less regularly, Lakers' matches (basketball) once in a while and some baseball or American football matches in New York. I was invited by corporate relations most of the time, so it was cheap for me. When I had to pay tickets myself, I paid up to $200 €$ for the Lakers for a crappy seat high up in the stands, [or] $70 €$ for the Canadians at the Molson [stadium] where I was not even able to see the puck. Very profitable for the stadium owners, forbidden to working-class people, no fan groups, but individuals buying team merchandise items. Crappy atmosphere (at least for the European I am), it is apparently what happened to English football with the antihooligan rules, and this is what will happen to French football. ${ }^{19}$

Once again, it would be better to target the real offenders rather than picking on everyone. Unless this is part of a strategy that aims at

19 Comment from this article: http://rue89.nouvelobs.com/2010/05/19/psg-la-securite-duparc-selon-lactionnaire-colony-capital-151840. 
eliminating working-class fans from stadiums to replace them with families, who will be able to buy food items and t-shirts while tickets will cost them a lot of money. [We will end with] a nice stadium full of arrogant "bourgeois" [comfortable middle/upper-class people], while the "other" [working-class] people will have to pay to watch matches on $T V .^{20}$

Just to eliminate 400 silly men perfectly known by the police as well as by the stadium's security staff, let's increase ticket prices by 4 or 5 times (just like MU [Manchester United] or Liverpool [England's two most successful clubs]) and thus let's prevent poor people from going to the stadium. Whereas it was already impossible for them to rent a flat in Paris, we will now prevent them from going to the stadium. ${ }^{21}$

Assimilating "ultra" fans from both [Boulogne and Auteuil] stands to all fans and eliminating the popular/working-class audience from the Parc [des Princes] is nothing more than a social cleaning of the [stadium's] stands to make more room for middle and upper classes, who will be more profitable for the club. ${ }^{22}$

Football has always been the people's sport. If it becomes the rich people's sport, then it will simply lose its soul. We must keep [ticket] prices attractive to allow all segments of the population to come to the stadium. ${ }^{23}$

A sports journalist whom we interviewed shared the same opinion:

The increase in prices, which has really been unbelievable - between 40 and 50\% - is just crazy. Such increase has completely changed the audience. It means [...] that PSG wanted to clean up "socially", through the wallet. (E)

Moreover, a study from the Institut de Veille Sanitaire (the French Institute for Public Health Surveillance) shows that there are twice as many smokers amongst the working class than in the middle and upper classes (Lauzeille et al., 2009: 3). Smoking in public places was forbidden under French law in 2007. Nevertheless, this was differently enforced in the French stadiums - in most stadiums, the club

${ }^{20}$ Comment from this article: http://rue89.nouvelobs.com/2010/08/19/supporters-du-psgpresumes-coupables-et-stigmatises-162948.

21 Comment from this article: http://rue89.nouvelobs.com/2010/08/09/les-supporteurs-dupsg-interpeles-samedi-non-au-chatiment-collectif-161530.

${ }^{22}$ Comment from this article: http://rue89.nouvelobs.com/2010/08/09/les-supporteurs-dupsg-interpeles-samedi-non-au-chatiment-collectif-161530.

${ }^{23}$ FB NY Comments on the "Je ne fait que partager !" post. (NB: we kept the grammar error as it appears in the title of the post). 
did not really care and does not pay any significant attention to this issue. In the PSG stadium, however, this law was strictly enforced, as a sports journalist mentions in one of our interviews:

It is true that between the moment a cigarette is lit and the moment a stadium staff member arrives, it often takes less than a minute. (D)

We argue that this was done deliberately to try to dissuade working class people from attending matches.

\subsubsection{Fan communities are targeted whereas sport entertainment consumers are favored}

PSG's control devices based on the "Leproux plan" were described by the fans as a way to discriminate and stigmatize all fans rather than eliminating the violent ones. Indeed, all fan groups were dissolved and banned. This is precisely what was explained by this fan:

Racism was the REAL problem in the Parc [des Princes], we agree. But it was a minority of fans, we still agree. But this is also what we rebuke. Should we congratulate a professor who punishes all students because 2 students show no respect? What makes me angry (among other things) is misinformation and even the discrimination PSG used toward its own fans. $^{24}$

Such statements recurred often on such fora. Another fan stated:

PSG fans are often pointed as very violent people; however, everybody knows that each club has its ULTRA [fans] and whenever there are ultra [fans], there is often some tension between rival clubs. But let's not forget that there are very simple fans who are very simple and support their team in the most respectful way with their families or friends. PSG fans make me think of young immigrant people from the suburbs who are very often ALL blamed when cars are burnt or when a bus stop is damaged! But out of about a hundred people, only ten would have been guilty. ${ }^{25}$

The "collective punishment" of fan groups was reflected by some of the official controls used against PSG fans. For example, Parisian fans (identified by, for example, the wearing of club colors or driving with a license plate from Paris or its

${ }^{24}$ Comment from this article: http://rue89.nouvelobs.com/2011/08/23/le-parc-des-princesabrite-desormais-un-public-de-consommateurs- 218868 .

${ }^{25}$ Comment from this article: http://rue89.nouvelobs.com/2010/12/18/les-supporters-du-psg -en-colere-contre-le-dedain-du-president-181346. 
suburbs) were not allowed access to the greater urban area surrounding the stadium on away match days (except for those who had a ticket). This attack on rights took the form of an "arrêté préfectoral" ("prefectural order") issued by the French government which grants specific, time-limited powers. One of the PSG fan group leaders whom we interviewed stated:

People have certainly been deprived of certain rights. Some fans, especially those who were traveling, were put in the same bag. They were labeled as dangerous people. So, in my opinion, this is not a positive thing. Basically, I think it [...] that if people want to travel to support a [football] club, it is not because they have a "75" [the Paris postal code's prefix] plate that they must be banned from the stadium or forbidden to buy tickets when they are traveling to a city. (B)

We argue that through such control practices, which are widely reported by the media, the image of football fans was seriously damaged, since the apparent (and unique) need for these measures implies a significant problem. Indeed, a fan explained that the image of a football fan is systematically associated with negative stereotypes:

We arbitrarily create a category of fans with [various] criteria [such as] violence, foolishness, racism, delinquency [...] ...easy stereotypes to promote. $^{26}$

A fan even ironically interpreted the way PSG fans are often described:

Highly violent with shaved hair, soaked with beer, yelling and provoking fights. ${ }^{27}$

We argue that such control devices are highly damaging to the image of football fans and promotes instead another type of audience member-the entertainment consumer. A new definition of what a fan is supposed to be in the neoliberal contemporary society is promoted. We argue that these disciplinary practices (re)directed the PSG audience member to a new role; that is, from an actual football fan to a (sport) entertainment consumer.

The PSG fan was shown as violent and racist by (1) the state, which prevented all fans from walking in the stadium area on away match days; (2) the police, which systematically arrested all fans on demonstrations; and (3) the club's management

${ }^{26}$ Comment from this article: http://rue89.nouvelobs.com/2010/08/09/les-supporteurs-dupsg-interpeles-samedi-non-au-chatiment-collectif-161530.

27 Comment from this article: http://rue89.nouvelobs.com/2010/08/19/supporters-du-psgpresumes-coupables-et-stigmatises-162948.

Vol. 19, No. 3 
practices towards its own fans. In short, the traditional PSG fan had to be eliminated. As promoted by PSG control devices, the PSG audience member should be now calm, docile, manageable, indifferent, and richer-the consumer figure was born.

Interestingly, a critical football $\operatorname{blog}^{28}$ written with humor/irony analyzed the Leproux plan by drawing upon the work of Naomi Klein (2007). It argued that the Leproux plan capitalized on different "shocks" in order to destroy the "fan personality" converting it into a "consumer personality". This could have various effects on different actors.

\subsubsection{Subjection, fatalism or resistance processes}

Some "past" fans had quietly accepted this new way of being a "fan"/member of the audience. Foucault has examined how an individual becomes a subject (the subjectification). As explained earlier, surveillance can impact upon subjectivation. This notion has also been investigated in the literature (Covaleski et al., 1998; Roberts et al., 2006; Lambert \& Pezet, 2011). Covaleski et al. (1998) show how partners in accounting firms can be transformed into "corporate clones" through self-subjection developed by mentoring and management by objectives techniques. Becoming a corporate clone means "duplicating the organization within the individual" (Covaleski et al., 1998: 294) through "techniques of the self". Through these techniques, the individual is "objectified" and becomes a "self-managing subject" (Covaleski et al., 1998: 294). That is what happened to this fan-after stating that the new atmosphere in the stadium is not good for "historical" fans like him and that he missed the previous atmosphere in the stadium, he added:

On the other hand, for all fathers who can finally bring their kids to the Parc [des Princes], it is magical. Now that I have a daughter, I tell myself that I would bring her with great pleasure to the "Leproux version" of the Parc whereas I would have probably never brought her to the "Ultra version" of the Parc. ${ }^{29}$

This is an example of how a fan was able to internalize the objectives of the club as his own. In the past, this fan would have never expressed the desire to go to the stadium with children. Going to the stadium meant rather shouting, singing, making noise, supporting his team and commenting the match with other football fans. The loud, enthusiastic fan was a self-selecting attendee of the Parc. Now, this fan saw the stadium as a venue for a "show" where he could bring his children like any other venue for entertainment shows (e.g., movies, concerts, etc.) and we argue that this was exactly the objective of PSG management. Hence, a dualism was

${ }^{28}$ www.moustachefootballclub.com.

${ }^{29}$ March 21, 2014 (PSG Club New York Facebook Fan Page). 
created in which there appeared to be no choice except either an upper middle class of docile, family-oriented consumers of football or a selfish, drunken and loud hooligan (who was not interested in his own children). This "new fan" was derided by traditional ones as someone who, until very recently, probably saw football as loutish but now saw an opportunity for self-promotion (Malcolm et al., 2000).

On the other hand, here is an example definition of what is (was) a fan-in sharp contrast to the new "desires" expressed by the fan above:

Going to the stadium is not about watching 11 millionaires kicking a ball [...], it's mystical and based on songs, rituals, an atmosphere, on a "Freudian" belonging to a team and to the football universe that sends us back to our childhood playground memories...And when all this happens in the Parc des Princes, with its clean architecture made of reinforced concrete, its perfect inclusion in the urban landscape, its exceptional acoustics, its history...one can only become addicted. ${ }^{30}$

Other "old" fans, for whom football was inextricably intertwined with what Lestrelin (2012) calls the relational engagement of fans with their clubs, have not been capable of internalizing this new category of "football consumer" and have excluded themselves from the stadium without engaging in resistance against this new category or role. This is often expressed through fatalism, which has already been shown as a reaction of male workers self-subjecting to the disciplinary power of accounting (Knights \& Collinson, 1987). In the case of PSG fans, fatalism meant the acceptance of the new situation, without self-subjecting to it. As fans stated:

...I don't go [to the stadium] anymore, it's too painful...it is not a temporary situation, the Parc [des Princes] is dead, that's it...we have to deal with it. ${ }^{31}$

That's the way it is - just watching tourists waving flags and people looking for their seats in the "virages" [cheaper and popular stands]. ${ }^{32}$

This sentiment recalls an interviewee of Kuper (2020: 6): "The violence in the Parc declined, but the atmosphere became a bit like England. I preferred the old ambience, even if it was an ambience with tear gas at the exits."

Nonetheless, some other "old" fans became engaged in resistance. Indeed, according to Foucault, there is always the potential of resistance in power

${ }^{30}$ Comment from this article: http://rue89.nouvelobs.com/2010/05/19/psg-la-securite-duparc-selon-lactionnaire-colony-capital-151840.

${ }^{31}$ February 25, 2013 (PSG Club New York Facebook Fan Page).

${ }^{32}$ FB NY Comments on the "It's official! If you are a PSG fan, you are a target!" post. 
relationships. These fans were highly critical towards the new role which is assigned to PSG audience members:

Clearly, the objective is to transform the Parc [des Princes] into a Disneyland where everybody is welcome. ${ }^{33}$

They want an audience made of followers who do not make waves and go to the stadium like others go to fashion shows. By the way, some players act as models in fashion shows. ${ }^{34}$

The Parc des Princes is not a circus or a movie theater. ${ }^{35}$

\subsubsection{Construction of the neoliberal audience member}

As shown above, the disciplinary control devices targeted the working-class and damaged the image of football fans - they were portrayed as a mixture of fans, the working-class, and violence. As a fan said:

However, I don't find it fair to increase ticket prices. Football is a popular/working-class sport, and working-class does not mean at all violent and poorly educated! ${ }^{36}$

We argue that the disciplinary control devices serve to construct the neoliberal audience member. He/she is supposed to be responsible for his/her own actions; but more than this, they are expected to behave in certain clearly defined ways. Thus, as a fan indicated:

If you are rich enough to buy Ibra, T. Silva and Cavani [three of the most expensive players in the history of the game at that time], you can allow fan groups and make sure that everything goes well by hiring control teams. $^{37}$

However, the club precisely did not want to hire control teams. It would rather have the audience members internalize this necessity of being quiet and calm. In a way, football was going through the transition phase from selling tickets to "undisciplined fans" to selling tickets to "football consumers". In the neoliberal

${ }^{33}$ February 25, 2013 (PSG Club New York Facebook Fan Page).

34 Comment from this article: http://rue89.nouvelobs.com/2010/12/18/les-supporters-dupsg-en-colere-contre-le-dedain-du-president-181346.

${ }^{35}$ FB NY Comments on the "It's official! If you are a PSG fan, you are a target!" post.

36 Comment from this article: http://rue89.nouvelobs.com/2010/08/19/supporters-du-psgpresumes-coupables-et-stigmatises-162948.

${ }^{37}$ March 21, 2014 (PSG Club New York Facebook Fan Page). 
world, people are responsible for their own behaviors (Lemke, 2001). In the ideal neoliberal world, there is no need for panopticon-based control systems any longer because people have internalized them through self-control-security forces, the state, club's policies are reduced to the minimum (Lemke, 2001). Moreover, the neoliberal audience member of a football match is both a consumer and an actor of a media show as explained by these fans:

Colony [PSG's previous owner] dreams of fans who would look like the nice and kind audience of "Stade Français" [Paris' leading rugby team rugby being considered as having a more convivial audience]. A TV-show audience, with beautiful girls on the forefront, smiling families who will pay their $50 €$ at half-time break in soft drinks and sandwiches, and a polite audience who will applaud when asked to do so. All of that topped with an "American style" at half-time break. This is promising... ${ }^{38}$

This crappy security plan hides a real marketing plan whose aim is to transform the Parc des Princes into Disneyland. ${ }^{39}$

And more pragmatically, how else could we analyze the ticket price increase, the fact that Colony Capital (like other football club owners) openly looks for new outlets, new markets... Football went from a popular sport $[\ldots]$ to an entertainment industry. ${ }^{40}$

Yeah, football is a sub-culture [pejorative]... for passionate and real fans, it's a popular culture like rap and graffiti... it's lived and appreciated by a lot of different people. Football had a sub-culture that has now become a sub-sub-sub-culture... It's becoming nothing more than a consumption place now. ${ }^{41}$

\subsection{Social discrimination}

The panopticon-based control devices can constitute a breach of human rights (this is not surprising as the panopticon was designed for totalitarian institutions from past centuries). Excluding some people from the stadium (and even from the greater urban area through the "arrêtés préfectoraux") on arbitrary grounds and/or

38 Comment from this article: http://rue89.nouvelobs.com/2010/05/19/psg-la-securite-duparc-selon-lactionnaire-colony-capital-151840.

39 Comment from this article: http://rue89.nouvelobs.com/2010/08/19/supporters-du-psgpresumes-coupables-et-stigmatises-162948.

40 Comment from this article: http://rue89.nouvelobs.com/2010/08/09/les-supporteurs-dupsg-interpeles-samedi-non-au-chatiment-collectif- 161530.

41 Comment from this article: http://rue89.nouvelobs.com/2010/12/18/les-supporters-dupsg-en-colere-contre-le-dedain-du-president-181346. 
as a preventive measure constituted a breach of human rights. This was the opinion of a former professional player who explained in one of our interviews:

We still need to think about this because it is a sensitive subject, which is not easy. For me, it is difficult to ban people from going to the stadium because it is also an attack on "freedom of expression". (A)

At the time of our data collection, in 2014, the "blacklist" of "potential" problematic fans was deemed illegal by the CNIL (the French commission whose aim is to protect individual freedom). ${ }^{42}$ Although PSG has been penalized for this practice, it continued to do so. Indeed, one sports journalist that we interviewed explained the following:

I think it would rather pay a fine of 100,000, 200,000, 500,000 Euros. [...] Here, I have the impression that cynically - because they will never say so in front of a microphone - they prefer to be punished for breaking the law, so that they can maintain their peace of mind, their funding, the visibility of their work over the years. (D)

The presumption of innocence no longer exists - families, friends, or simply seat neighbors are put under surveillance and sometimes also excluded from the stadium. While only a handful of fans were actually guilty of causing violence, all fan groups have been banned and dissolved. As a fan explains:

It's a bit like if you lived in a village and one resident of that village kills somebody, all other villagers, the inhabitants of that village, are considered killers... What would you think ? $^{43}$

Or, as another fan says:

When, one day, you will be banned from taking public transportation because there was an attack against one person in your train, maybe you will understand the issue raised by these fans. ${ }^{44}$

PSG fans who demonstrate peacefully were systematically taken to the police. Then, these people were administratively and systematically prohibited from accessing the stadium, without any legal judgment allowing PSG or stadium staff

42 See https://www.lexpress.fr/actualite/societe/psg-la-liste-d-exclusion-de-supporteursretoquee-par-la-cnil_1563958.html

43 Comment from this article: http://rue89.nouvelobs.com/2010/08/19/supporters-du-psgpresumes-coupables-et-stigmatises-162948.

44 Comment from this article: http://rue89.nouvelobs.com/2010/08/09/les-supporteurs-dupsg-interpeles-samedi-non-au-chatiment-collectif-161530. 
to proceed as such. Then, they needed to go to court, where they generally prevailed but the procedure took a long time. This was explained as follows:

At the end, not a single outrage, but 80 interpellations for identity checks. Identity checks that are generally not followed by custody because there is nothing wrong, but will "allow" (it's the chief of police's vision-to see his different statements on this subject matter in the media) to justify an administrative prohibition to enter the stadium [...]. The procedure of getting these decisions overturned is very long but in the vast majority of cases, it proves targeted fans right. ${ }^{45}$

If a fan was banned from the stadium, he/she was expected to make two mandatory check-ins at the police station during each match. This fan explained that even previous famous French demonstrations of workers, or people living illegally in the country did not lead to such massive arrests, in contrast to the PSG fan peaceful demonstrations:

When the undocumented [immigrants] demonstrate, they do not get arrested and expelled! Here, the demonstration did not generate any trouble but at the end, the law was not respected. The workers from Continental ${ }^{46}$ destroyed everything and received minimal penalties... [...] we are talking about a demonstration without any issues where people are being deported to police stations with penalties given without trial, without the right to defend oneself and everyone in the same bag! Try now to support your team as a PSG (or other team) fan and see whether your fundamental rights are respected! Without causing any trouble, you are treated as a criminal! It's like if all the workers from Continental were put in jail whereas only 2 or 3 destroyed everything. ${ }^{47}$

The fundamental freedoms of PSG fans were not respected within the stadium (the freedom to sing, to move freely, to sit at a specific place, etc.):

[...] I only want one thing - to be in the Parc [des Princes] as a seasonticket holder, to sit where I want (isn't it unbelievable that I am not allowed to choose where I want to sit?), with my friends (and not with

${ }^{45}$ Comment from this article: http://rue89.nouvelobs.com/2010/08/09/les-supporteurs-dupsg-interpeles-samedi-non-au-chatiment-collectif-161530.

${ }^{46}$ Here, the fan referred to a famous revolt of French workers from the Continental company (manufacturing tires) in 2009, trying to avoid the shutdown of their plant.

${ }^{47}$ Comment from this article: http://rue89.nouvelobs.com/2010/08/19/supporters-du-psgpresumes-coupables-et-stigmatises-162948.

Vol. 19, No. 3 
Neoliberal control devices and social discrimination:

The case of Paris Saint-Germain football club fans

unknown people), peacefully, singing the songs I want —and not the imposed songs, what a joke! ${ }^{48}$

As another fan explained, they were prevented from celebrating the goals of their team:

When there is a goal, they now put a very loud music, which covers all the [fan] songs and prevents us from celebrating the goals as we used to do before. $^{49}$

When disciplinary control devices tend to prevent working-class people or lively fans from coming to the stadium, they also breach human rights because they are discriminatory. Moreover, the loss is significant-they are not able/allowed to support their team anymore. PSG did not care about the football fan experience (the toilets are bad; the food is bad; the whole event is too short - people are herded into the stadium and out again as quickly as possible). There was no investment in basic human rights. This contrasted sharply with the luxury image broadcast on TV.

Foucault (2004b: 40-45) distinguishes two ways to make Law (the "rights" of people) and Government (the art of ruling people). On one hand, there are the "fundamental rights" with "revolutionary characteristics" (French Revolution/Rousseau/natural rights) — law and rights are the starting point to then define the "borders of the action of the government" (Foucault, 2004b: 40-41). On the other hand, there are the "rights of the governed people" going with the liberal idea of a (non-)utility of government (English political radicalism) -we start from "the practice of government" to analyze the "limits" of that practice (Foucault, 2004b: 41-42). Foucault (2004b: 43) explains that when people lay claims about their rights, it can deal with "human rights" but also with "the independence of the governed people", the two building on different conceptions of freedom.

This social discrimination concerned many people. Indeed, as one former senior member of a famous PSG fan group explains in one of our interviews:

Today, we're missing a population that I estimate at 8,000-10,000 fans, who used to come and who don't come anymore [to the stadium]. (C)

48 Comment from this article: http://rue89.nouvelobs.com/2010/08/19/supporters-du-psgpresumes-coupables-et-stigmatises-162948.

49 February 25, 2013 (PSG Club New York Facebook Fan Page). 


\subsection{What is the "social efficiency" of the neoliberal control devices?}

The PSG situation appears to have improved, since there is no more violence within the stadium. However, if violent fans are now excluded from the stadium, they are still free in "real life" and can thus exert their violence in other ways. For instance, it has been reported that certain violent PSG fans now attend and significantly disrupt matches of the PSG women's team (e.g. Krishnan, 2019), the other Parisian clubs (Paris FC and Red Star) and local amateur clubs (SaintGermain FC). This is common knowledge, as explained by one fan on the NewYork PSG fans Facebook page:

For the record, offenders excluded from PSG fan organizations have rallied behind PARIS FC, I'm curious to see what happens in L2 next season... ${ }^{50}$

Violent acts from football fans have also been reported outside the football world (certain AS Saint-Étienne [a club from the south-east of France] fans recently disturbed and caused damage at the wedding of a presumed Olympique Lyonnais [a Lyons-based club] fan). ${ }^{51}$ We can thus question the social efficiency of these neoliberal control devices: do they really engender a positive evolution of wellbeing in society? Indeed, peaceful PSG fans cannot live their normal fan life, whereas violent PSG fans found other locations for their actions. What is sure is that the Qatari owners have drastically increased their economic revenues and their image thanks to the implementation of such control devices. Lastly, we can note that neoliberal governance appears unable to create new social links between people. If social communities of fans have disappeared at PSG, no other communities have replaced them. People now simply bring their own family or friends to the stadium with them.

\section{Discussion and conclusion}

We asked how neoliberal control was exercised over football fans and what the results of these devices were on fans. Through "netnographic" data and interviews with key actors and stakeholders in the football field, we highlight the various methods of control exercised by and around Paris Saint-Germain Football Club; how these measures significantly blurred the distinction between PSG as a private enterprise and the French state as a legislative/judicial entity; how the result is a spectrum of outcome behaviors from fan self-exclusion and self-policing to the

${ }^{50}$ FB NY Comments on the "It's official! If you are a PSG fan, you are a target!" post.

${ }^{51}$ See https://www.lefigaro.fr/le-scan-sport/2016/01/07/27001-20160107ARTFIG00052prison-ferme-pour-des-ultras-stephanois-qui-pensaient-avoir-saccage-le-mariage-d-unlyonnais.php

Vol. 19, No. 3 
enforced removal of a largely working class portion of the club's fans; and in the ways these fans protected themselves from this control. We argue that this creates a "panopticon"-like situation in which, whether actively surveilling or not, makes no distinction between the "legitimate" reduction of intra-fan violence by a small minority and the wider, negative impact on the majority of fans' ability to exercise basic rights, both inside the stadium and in the city beyond.

It has been widely argued in the literature (see for example Brivot \& Gendron, 2011; Martinez, 2011) that the panoptical metaphor is no longer useful for describing the control devices of contemporary society. It has been shown that modern modes of control rely more on fluidity and openness in new digitalized environments, far beyond the rigidity and closeness of the lone prison guard's ceaseless observation of his inmates in Bentham's panopticon. Martinez (2011) built on Deleuze's "society of control" to understand more modern modes of control, whereas Brivot and Gendron (2011) built on extended concepts from Foucault such as power, visibility and resistance, which they see as encapsulating the "complexities" and "ramifications" of modern modes of control. We argue that such archaic panopticon-based modes of control and surveillance ${ }^{52}$ (described by Foucault from total institutions in the $18^{\text {th }} \& 19^{\text {th }}$ centuries - for example from prisons and psychiatric hospitals) still exist in contemporary society. Because of their archaic characteristics, such disciplinary control devices breach some human rights.

In the case of PSG, disciplinary control devices were implemented as a physical and psychological effort (as illustrated by the panopticon metaphor) to change the PSG fan's identity or possibly to "recruit" new ones. Our paper mainly deals with what we label as "true" PSG fans. This "true" or "real" fan notion is introduced and defined by Oxford's Social Issues Research Centre in its 2008 "Football Passions" report $^{53}$ commissioned by Canon. This report defines the "true" fans as the ones who feel the pressing need to attend the stadium to live their passion and who have high psychological and emotional involvements associated with this experience in the stadium (pp. 14-15). Therefore, "true" fans banned from the stadium feel high (psychological and emotional) loss. We interpret that loss as a breach of a human right. The report explains that a "true" fan cries during a match (p. 10) and sees football as a religion (p. 9). It shows that football is vital for this type of fan. Exclusion is seen as an important disciplinary mechanism in Foucault's work. The report also shows the importance of different rituals (songs, demonstrations, etc.) in building and maintaining a fan community (pp. 25-26). Thus, through its control devices that prevented fans from maintaining that community, PSG management targeted the "true" fans (those who care about rituals, who see their role as

${ }^{52}$ In any case, Foucault's panopticon was always intended as more of a metaphor for how "discipline of the self" is animated.

${ }^{53}$ See http://www.sirc.org/football/football_passions.pdf 
participants - not mere spectators (p. 13) - and who are highly psychologically and emotionally involved). Interestingly, the report also provides data such as the heart rate of a PSG fan that was measured during the 2008 PSG vs. Monaco match (p. 60), which shows the high involvement of PSG fans. Finally, it also highlights the difficult relationships between the police and PSG fans (p. 53). The club's management tried to make the PSG fan identity evolve - the identity concept can be linked here to the notion of the self developed by Foucault. Indeed, by imposing a discipline on the self, it tries to act upon the PSG fan identity. We tried to show that this discipline of the self, imposed by PSG management, follows a neoliberal rationality, leading to a new fan figure (the mere spectator), that is a form of domination.

Our aim was to show how PSG fan identity transformation (launched by the new PSG management) promotes a "neoliberal fan". To that end, we described the recent PSG owners/executives/managers' actions (with the support of the state and many other private stakeholders like TV-channels and so on) as a neoliberal attempt to transform the fan figure. But this did not entirely succeed. Indeed, the key features of the neoliberal rationality lie in different aspects. Let us explain these aspects.

Power does not only come from the state, but from allied institutions. In the neoliberal world, people are deemed to be responsible for their own behaviors (Lemke, 2001). Social issues (employment, health, etc.) are seen as individual (self-)issues, thus there is a necessity for self-regulation (Lemke, 2001). Freedom, individualism, and "choice" are seen as important. State and police forces are reduced to a minimum (nevertheless, Foucault demonstrates that this state reduction is a state strategy in itself). At a time in which football has become an increasingly professionalized sport, a neoliberal approach can be seen as clubs seek absolute control on and off the pitch (Alonso-Gonzalez, 2017). The market dominates; the economic view is important (Lemke, 2001). Fans are considered as a source of income (economics takes precedence over politics).

In the actions attempted by the PSG executives to transform the fan figure, we can see these aspects of the neoliberal rationality working. Nevertheless, the evolution of PSG fan identity does not fully match with neoliberal rationality. In the PSG case, we saw that the PSG executives consider the PSG fans as "ticket purchasers", so only for their economic capital. Fans are considered for the income they earn (richer people buy expensive tickets and are likely to be more beautiful and quieter - a widespread idea found in our data quotes). Fans are seen as a source of revenue for PSG executives in the economic field (money) but also in the marketing field (image). This is how they see fans, and this is how they would like them to be. Perhaps this correctly describes some of the new fans coming into the stadium.

But that fails to describe all fans. "Real" fans are much more than that. The neoliberal rationality fails to consider some "real" fan values like loyalty, 
communities, and belonging feelings (as detailed above, and as described by Lestrelin, 2012). The neoliberal rationality fails to encompass what "real" fans are. Therefore, the neoliberal attempt of the PSG executives has only partly succeeded. Indeed, we can be critical towards the neoliberal attempt of the PSG executives because it negates the social and historical issues around "real" fans. That is why they did not fully succeed in managing these "real" fans. Individualizing them or calling for their self-regulation does not work for "real" football fans. Indeed, "real" fans are unable to produce their satisfaction on their own-they need a community to sing, gather, interact with their team, etc. This has been highlighted by fan reactions to games being played in empty stadiums as play resumed in European countries affected by the coronavirus outbreak in 2020, during which fans report an exclusion summed up by Doyle (2020): "To be a fan is to be part of something much bigger, a wider community."

Our paper contributes to the articulation of "discipline" and "government" (the two major power techniques in Foucault's work). When Foucault began his governmentality analysis - "the conduct of the conduct" - he moved away from the disciplinary society. Indeed, if we think of ideal neoliberal techniques of government, there is no need for disciplinary (panopticon-based) control devices any longer because people have internalized these devices through self-control: security forces, the state, the club's policies are reduced to the minimum (Lemke, 2001). Nevertheless, "discipline" and "government" are not necessarily mutually incompatible. As explained by Di Vittorio (2005: 102-103), "the proliferation of disciplinary mechanisms determines an 'overall surveillance' regime and prepares the field on which biopolitical mechanisms are going to arise from the end of the $18^{\text {th }}$ century. [...] In 1976, in 'Il faut défendre la société' and in 'La volonté de savoir', Foucault begins to strictly distinguish the disciplinary power from the biopower and sees the normalization society in terms of an articulation between disciplinary and biopolitical mechanisms" ${ }^{, 54}$. In our paper, we show how disciplinary mechanisms can be useful in the implementation of a neoliberal governmentality.

We also contribute to the management control literature by showing that seeing control devices as enabling or constraining depends upon the point of view which is taken. Considered from the view of the PSG executives, control devices enabled them to select and choose the fans they want. Considered from the view of the PSG "real" fans, control devices were much more than constraining - they breached

${ }^{54}$ Our translation of the original version: « La prolifération des mécanismes disciplinaires détermine un régime de «surveillance généralisée » et prépare le terrain sur lequel vont se greffer, à partir toujours de la fin du $18^{\text {ème }}$ siècle, les mécanismes biopolitiques. [...] En 1976, dans «Il faut défendre la société » et dans «La volonté de savoir », Foucault distingue désormais nettement le pouvoir disciplinaire du biopouvoir et il envisage la société de normalisation en termes d'articulation des mécanismes disciplinaires et des mécanismes biopolitiques » (Di Vittorio, 2005: 102-103). 
their human rights. We thus contribute to the literature by showing how neoliberal control devices can be implemented to discriminate against people on sociological grounds, thereby impeding the development of an equal and harmonious social life. However, in the Foucauldian theory, disciplinary and government powers are not only described as constraining. According to Foucault, power is used over free subjects. In "Surveiller et Punir" (1975: 242), the panopticon is described as creating a "positive" power: "it deals with increasing the strengths of social forces - increasing production, developing the economy, spreading education, increasing the level of public moral; growing and multiplying". ${ }^{55}$ Thus, according to Foucault, such disciplinary control devices could lead to a certain form of social progress. Indeed, for Foucault, disciplinary power is not seen as constraining but rather as enabling a better administration of society. We argue that as soon as control devices appear to breach human rights, any social progress of any kind is no longer possible.

\section{Acknowledgments}

We would like to thank Matias Laine, Peter Pope and the participants of the $26^{\text {th }}$ International Congress on Social and Environmental Accounting Research in Saint Andrews, the Symposium on Accounting and Popular Culture of the $38^{\text {th }}$ European Accounting Association Annual Congress, in Glasgow, the $36^{\text {ème }}$ Congrès de l'Association Francophone de Comptabilité in Toulouse, the $3^{\text {rd }}$ French Congress on Social and Environmental Accounting Research (CSEAR France) in CergyPontoise, and the $10^{\text {th }}$ Spanish Conference on Social and Environmental Accounting Research (CSEAR Spain) in Seville for their valuable comments and feedback on earlier versions of this paper. Charles Cho would like to thank Aude Devon for her outstanding research assistance and gratefully acknowledges the financial support provided by the ESSEC Research Centre (CERESSEC) and the Erivan K. Haub Chair in Business \& Sustainability at the Schulich School of Business. Michael Rogerson gratefully acknowledges the funding contributions of the Economic and Social Research Council (UK) [grant reference ES/P000630/1].

\section{References}

Ahrens, T. \& Chapman, C.S. (2007) "Management accounting as practice", Accounting, Organizations and Society, vol. 32, no. 1-2: 1-27

Alonso-Gonzalez A., Alamo-Hernandez P. \& Peris-Ortiz M. (2017) "Guardiola, Mourinho and Del Bosque: Three different leadership and personal branding styles”, in Peris-Ortiz, M., Álvarez-García, J. \& Del Río-Rama,

55 Our translation of the original version: «Il s'agit de rendre plus fortes les forces sociales - augmenter la production, développer l'économie, répandre l'instruction, élever le niveau de la morale publique; faire croître et multiplier » (Foucault, 1975: 242).

Vol. 19, No. 3 
M. (eds.) Sports Management as an Emerging Economic Activity, Cham: Springer

Arnold, P.J. (1998) "The limits of postmodernism in accounting history: The Decatur experience", Accounting, Organizations and Society, vol. 23, no. 7: 665-684

Arnold, P.J., (2009) Global financial crisis: The challenge to accounting research, Accounting, Organizations and Society, vol. 34, no. 6-7: 803-809

Arnold, P.J. (2012) "The political economy of financial harmonization: The East Asian financial crisis and the rise of international accounting standards", Accounting, Organizations and Society, vol. 37, no. 6: 361-381

Bentham, J. (1995) The Panopticon Writings, London: Verso

Brivot, M. \& Gendron, Y. (2011) "Beyond panopticism: On the ramifications of surveillance in a contemporary professional setting", Accounting, Organizations and Society, vol. 36, no. 3: 135-155

Cooper, C. (2015) "Entrepreneurs of the self: The development of management control since 1976", Accounting, Organizations and Society, vol. 47: 14-24

Covaleski, M.A., Dirsmith, M.W., Heian, J.B. \& Samuel, S. (1998) "The calculated and the avowed: Techniques of discipline and struggles over identity in big Six public accounting firms", Administrative Science Quarterly, vol. 43, no. 2: 293-327

Covaleski, M.A., Dirsmith, M.W. \& Weiss, J.M. (2013) “The social construction, challenge and transformation of a budgetary regime: The endogenization of welfare regulation by institutional entrepreneurs", Accounting, Organizations and Society, vol. 38, no. 5: 333-364

Curtis, B. (2002) "Foucault on governmentality and population: The impossible discovery", Canadian Journal of Sociology, vol. 27, no. 4: 505-533

de Sa Pereira, M.P. (2012) "Paris is earning", The Classical, available on-line at https://web.archive.org/web/20120131083608/http://theclassical.org/article s/paris-is-earning [Accessed 4 July 2020]

Detchessahar, M. (2015) Le marché n'a pas de morale, ou l'impossible société marchande, Paris : Editions du Cerf

Di Vittorio, P. (2005) "De la psychiatrie à la biopolitique, ou la naissance de l'état bio-sécuritaire", in Beaulieu, A. (ed.) Michel Foucault et le contrôle social, Québec: PU Laval

Doyle, L. (2020) "How distributing PPE has helped me and other football fans through the uncertainty of coronavirus", The Independent, available on-line at https://www.independent.co.uk/sport/football/premier-league/nhs-ppecoronavirus-pandemic-merseyside-hub-volunteer-a9544111.html [Accessed 5 July 2020]

Doyle, P. (2006) "Man killed as PSG fans run amok", The Guardian, available online at https://www.theguardian.com/sport/blog/2006/nov/24/fankilledas psgfansrunamo [Accessed 4 July 2020]

Everett, J. (2003) "The politics of comprehensive auditing in fields of high outcome and cause uncertainty", Critical Perspectives on Accounting, vol. 14 , no. 1-2: $77-104$ 
Farjaudon, A-L. \& Morales, J. (2013) "In search of consensus: The role of accounting in the definition and reproduction of dominant interests", Critical Perspectives on Accounting, vol. 24, no. 2: 154-171

Foucault, M. (1975) Surveiller et Punir : Naissance de la Prison, Paris: Gallimard

Foucault, M. (1994) "Le jeu de Michel Foucault", Dits et Ecrits 1976-1979, Tome III, texte $\mathrm{n}^{\circ}$ 206, Paris: Gallimard

Foucault, M., (2003) Society must be defended: lectures at the Collège de France, 1975-76, New York: Picado

Foucault, M. (2004a) Sécurité, Territoire, Population, Cours au Collège de France, 1977-1978, Paris: Gallimard, Seuil

Foucault, M. (2004b) Naissance de la biopolitique, Cours au Collège de France, 1978-1979, Paris: EHESS, Gallimard, Seuil

Giddens, A. (1979) Central Problems in Social Theory, London and Basingstoke: The Macmillan Press Ltd.

Hardt, M. \& Negri, A. (2000) Empire, Cambridge: Harvard University Press

Horncastle, J. (2018) "Davide Astori's death leaves Florence and Italy in a state of shock", $B B C$, available on-line at https://www.bbc.co.uk/sport/football/ 43279579 [Accessed 6 July 2020]

Jupe, R. (2012) "The privatization of British energy: Risk transfer and the state", Accounting, Organizations and Society, vol. 37, no. 2: 116-129

Klein, N. (2007). The Shock Doctrine: The Rise of Disaster Capitalism, Toronto: Knopf Canada

Knights, D. \& Collinson, D. (1987) "Disciplining the shopfloor: A comparison of the disciplinary effects of managerial psychology and financial accounting", Accounting, Organizations and Society, vol. 12, no. 5: 457-477

Krishnan, J. (2019) "Chelsea Women 2 PSG Feminine 0: Crowd trouble mars impressive Women's Champions League victory", Evening Standard, available on-line at https://www.standard.co.uk/sport/football/chelseawomen-2-psg-feminine-0-result-crowd-trouble-mars-impressive-womenschampions-league-victory-a4098146.html [Accessed 5 July 2020]

Kuper, S. (2020) "Simon Kuper on the rise of PSG", Financial Times, available on-line at https://www.ft.com/content/b027e684-0238-48ff-acb0-37edd203 08fd [accessed 25 August 2020]

Lambert, C. \& Pezet, E. (2011) "The making of the management accountant Becoming the producer of truthful knowledge", Accounting, Organizations and Society, vol. 36, no. 1: 10-30

Lauzeille, D., Marchand, J.-L., Ferrand, M. (2009) Consommation de tabac par catégorie socioprofessionnelle et secteur d'activité ; outil méthodologique pour l'épidémiologie, Institut de Veille Sanitaire

Lemke, T. (2001) “"The birth of bio-politics': Michel Foucault's lecture at the Collège de France on neo-liberal governmentality", Economy and Society, vol. 30, no. 2: 190-207

Lestrelin, L. (2012) "Entering into, staying, and being active in a group of football supporters: A procedural analysis of engagement. The case of supporters of 
a French football club", International Review of Sociology (Revue Internationale de Sociologie), vol. 22, no. 3: 492-513

Malcolm, D., Jones, I. \& Waddington, I. (2000) "The people's game? Football spectatorship and demographic change", Soccer \& Society, vol 1, no. 1: $129-143$

Martinez, D. E. (2011) "Beyond disciplinary enclosures: Management control in the society of control", Critical Perspectives on Accounting, vol. 22, no. 2: 200-211

Miller, P. \& O'Leary, T. (1994) "Accounting, "economic citizenship" and the spatial reordering of manufacture", Accounting, Organizations and Society, vol. 19 , no. 1: $15-43$

Miller, P., \& O'Leary, T. (1987) "Accounting and the construction of the governable person”, Accounting, Organizations and Society, vol. 12, no. 3: 235-265

Mouillard, S. (2010) "Pourquoi la guerre des tribunes reprend au PSG", Libération, available on-line at https://www.liberation.fr/sports/2010/03/03/pourquoila-guerre-des-tribunes-reprend-au-psg_613142 [Accessed 12 July 2020]

Næss, H.E. (forthcoming) "Sociology and the ethnography of human rights at mega-sport events", Current Sociology

Navarro, A. (2015) "The lowdown on the Parc des Princes" Real Madrid, available on-line at https://www.realmadrid.com/en/news/2015/10/the-lowdown-onthe-parc-des-princes [Accessed 4 July 2020]

Neu, D. (2006) "Accounting for public space", Accounting, Organizations and Society, vol. 31, no. 4-5: 391-414

Oakes, L.S., Townley, B. \& Cooper, D.J. (1998) "Business planning as pedagogy: Language and control in a changing institutional field", Administrative Science Quarterly, vol. 43, no. 2: 257-292

Preston, A.M., Cooper, D.J. \& Coombs, R.W. (1992) "Fabricating budgets: A study of the production of management budgeting in the National Health Service", Accounting, Organizations and Society, vol. 17, no. 6: 561-593

Reiche, D. (2015) "Investing in sporting success as a domestic and foreign policy tool: The case of Qatar", International Journal of Sport Policy and Politics, vol. 7, no. 4: 489-504

Reyes-Zaga, H.A. (2014) "Biopolitics and disposable bodies: A critical reading of Almazán's Entre perros", Latin American Perspectives, vol. 41, no. 2: 189-201

Roberts, J., Sanderson, P., Barker, R., Hendry, J. (2006) "In the mirror of the market: The disciplinary effects of company/fund manager meetings", Accounting, Organizations and Society, vol. 31, no. 3: 277-294

Ryder, A. (2013) "Foucault and Althusser: epistemological differences with political effects", Foucault Studies, vol. 16: 134-153

Shea, A. (2018) "The last of the ultras: Paris Saint-Germain and the repression of football fans in France", These Football Times, available on-line at https://thesefootballtimes.co/2018/02/28/the-last-of-the-ultras-psg-and-therepression-of-football-fans-in-france/ [Accessed 3 July 2020] 
Simons, R. (1990) "The role of management control systems in creating competitive advantage: New perspectives", Accounting, Organizations and Society, vol. 15, no. 1-2: 127-143

Tsoukala, A. (2013) "Controlling football-related violence in France: Law and order versus the rule of law", Sport in Society, vol. 16, no. 2: 140-150

Tyner, J.A. (2004) "Self and space, resistance and discipline: A Foucauldian reading of George Orwell's 1984", Social \& Cultural Geography, vol. 5, no. 1: 129-149

Uddin, S. (2009) "Rationalities, domination and accounting control: A case study from a traditional society", Critical Perspectives on Accounting, vol. 20, no. 6: 782-794

Watt, H., Newell, C. \& Bryant, B. (2014) "Qatar World Cup 2022 scandal: Bill Clinton's fury at vote triggered global search for truth", The Telegraph, available on-line at: https://www.telegraph.co.uk/sport/football/worldcup/10871114/Qatar-World-Cup-2022-scandal-Bill-Clintons-fury-at-votetriggered-global-search-for-truth.html [Accessed 3 August 2020] 